\title{
Cloudiness over the oceans at subarctic latitudes as a visible part of atmospheric moisture transport
}

\author{
M. Aleksandrova ${ }^{1}$ \\ Received 1 September 2020; accepted 7 September 2020; published 1 February 2021.
}

The article analyzes the climatology and interannual variability of fractional total and low cloud cover in the subarctic and subpolar regions of the North Atlantic and the North Pacific. We used surface visual observations of cloudiness from voluntary observing ships (VOS) for the period from 1950 to 2017. It is shown that in the North Atlantic and the North Pacific seasonal variations of the mean cloud cover demonstrate contrasting character. For a better identification of regional features, the probability distributions of the fractional cloud cover were analyzed. Analysis of interannual variability shows that in many areas of the North Atlantic and the North Pacific, significant linear trends in both total and low cloud cover are observed. Moreover, in the North Pacific, linear trends in the total cloudiness have pronounced seasonality. KEYWORDS: Subarctic cloudiness; visual cloud observation; cloud climatology over the ocean; long-term trends in cloud cover.

Citation: Aleksandrova, M. (2020), Cloudiness over the oceans at subarctic latitudes as a visible part of atmospheric moisture transport, Russ. J. Earth. Sci., 21, ES1004, doi:10.2205/2020ES000738.

\section{Introduction}

Cloud cover over the oceans plays an important role in the Earth's climate system. Clouds affect the fluxes of short-wave [Aleksandrova et al., 2007; Dobson and Smith, 1988 and long-wave [Josey, 2003] radiation, implying serious consequences for atmospheric moisture transport and influencing meridional transports in the ocean [Ushakov and Ibrayev, 2018 and in the atmosphere [Dufour et al., 2016. As one of the elements of the climate system, cloudiness has an indirect effect on regional changes in various oceanographic characteristics of the global ocean including Arctic [Pisareva, 2018; Travkin and Belonenko, 2019, Vlasova et al., 2019]. Also, cloud cover can serve as an indicator of global and regional climate change, including both intrinsic and forced variability [Chernokulsky et al., 2017. In the recent decade, the fastest

\footnotetext{
${ }^{1}$ Shirshov Institute of Oceanology RAS, Moscow, Russia

Copyright 2020 by the Geophysical Center RAS. http://rjes.wdcb.ru/doi/2020ES000738-res.html
}

rate of global warming has been observed in the Arctic [Bekryaev et al., 2010, Serreze and Barry, 2011. Thus, the analysis of the Arctic cloud cover is very relevant for understanding the mechanisms of changes.

Climate changes in the Arctic are particularly characterized by declining sea ice extent potentially closely related to variations in cloudiness through the mechanisms of atmospheric moisture content affecting warming [Dufour et al., 2016] and impact on incoming shortwave radiation. For example, Wille et al. 2019 show that atmospheric rivers providing anomalous moisture transports, are associated with the massive frontal cloud systems. Moreover, cloud cover is engaged in a number of Arctic climate feedbacks also playing important role in the Arctic climate change. Kay and Gettelman 2009] demonstrate that sea ice extent can control the amount of low cloud cover with increasing low level clouds over open water.

The variability of cloud cover in the Arctic is sensitive to different atmospheric circulation indices. Chernokulsky and Esau 2019] show that the strongest correlations were found in the Barents 
and Kara Seas, and the correlations with low cloud cover are stronger than with total cloud cover. These correlations are most pronounced in autumn and winter.

\section{Data and Method}

Information about cloud cover can be obtained from various sources, including satellite data, reanalysis and direct measurements at weather stations and ships. Satellite data are quite accurate and relatively homogeneous in terms of sampling, but their records limited by 1984 [Frey et al., 2008, Foster and Heidinger, 2013, Karlsson et al., 2013, Rossow and Schiffer, 1991, 1999, Stubenrauch et al., 2013. Cloud cover information from reanalysis becomes more accurate with increasing product resolution and parameterizations. However, reanalysis cloud cover still demonstrates biases compared to observations and require further validation [Bedacht et al., 2007, Chernokulsky and Mokhov, 2012. In the Arctic, cloudiness in different reanalysis demonstrate significant uncertainties in the monthly means, especially in the winter season [Liu and Key, 2016. Chernokulsky and Mokhov 2012 show significant biases in the average cloudiness from reanalysis in the Arctic compared to surface observations and satellite data.

Direct surface visual observations of fractional cloud cover over the oceans remain a unique source of long-term information about cloudiness. Over the oceans, the most complete collection of historical visual observations is provided by voluntary observing ships (VOS) and available from the International Comprehensive Ocean-Atmosphere Data Set (ICOADS) [Freeman et al., 2017; Woodruff et al., 2011.

Visual VOS observations of cloud cover provide the longest record, starting in the mid-nineteenth century. However, this data set is characterized by spatial and temporal heterogeneity of sampling [Gulev et al., 2007a, 2007b with most observations being concentrated along the main ship routes in the North Atlantic and the North Pacific. In these regions the seasonal number of available reports typically closely matches or exceeds 300 reports per $2^{\circ}$ grid cell with more than 500 reports in some gird cells [Aleksandrova et al., 2018]. Over the central
North Pacific and the North Atlantic between $50^{\circ} \mathrm{N}$ and $65^{\circ} \mathrm{N}$ the seasonal number of total cloud cover reports is about 200 reports per $2^{\circ}$ grid cell. At high latitudes, this number decreases significantly due to smaller number of merchant ships and sea ice impact on navigating conditions especially in winter. Over most of the Arctic Ocean the mean seasonal number of reports per $2^{\circ}$ grid cell does not exceed $10-15$ reports, making it is possible to consider climatology of cloud cover and its variability only in the Barents Sea and in the southeastern part of the Greenland Sea, where the amount of observations varies within 50-150 reports per season per $2^{\circ}$ grid cell.

Also, visual observations from ICOADS are characterized by temporal sampling inhomogeneity. The last part of the 19th century and the first half of the 20th century are characterized by relatively small amount of data. In the second half of the 20th century, the number of reports containing information about cloud cover is increasing significantly. Most observations were carried out from the late 1960s to the late 1980s with the period after 1990s being characterized by declining trend in the number of observations resulting in twice as small number of data in the last years compared to the period before 1990s. All calculations were performed for individual seasons (JanuaryMarch (JFM), April-June (AMJ), July-September (JAS), October-December (OND)). This approach accounts for strong temporal changes in observational density.

In addition to the ICOADS quality control checks, we excluded from the analysis all reports indicating unrealistic values confirmed by the analysis of alternative parameters, for example when low cloud cover is higher than the total cloud cover, or the reports indicating precipitation under a clear sky. In ICOADS, cloud cover is presented in octas (eighths) ranging from 0 to 8 , according to the WMO manual [WMO, 1974]. There is also an additional code "9", which means "sky obscure, cloud cover cannot be observed". To include in the analysis as much data as possible, cases, when precipitation was reported under cloud code "9", all reports with "9" were consolidated with 8 octa category. This resetting resulted in an increased number of reports with overcast approximately $2 \%$.

We consider here climatology and variability of cloud cover in the North Atlantic and the North Pa- 
(a) total cloud cover (JFM)

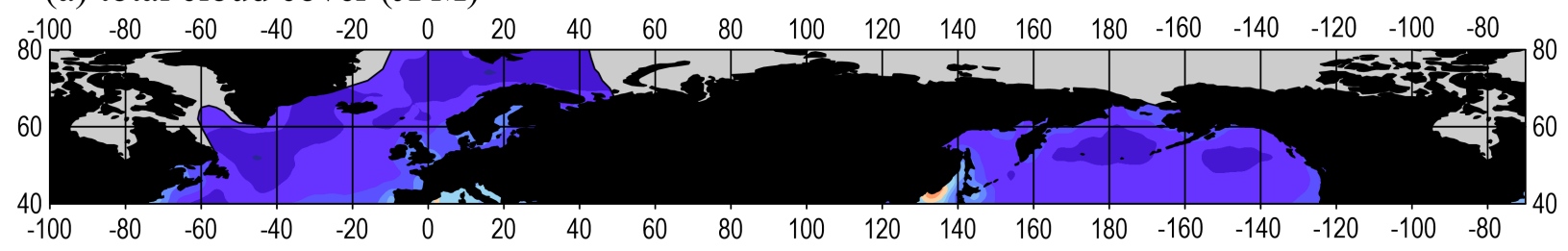

(b) total cloud cover (JAS)
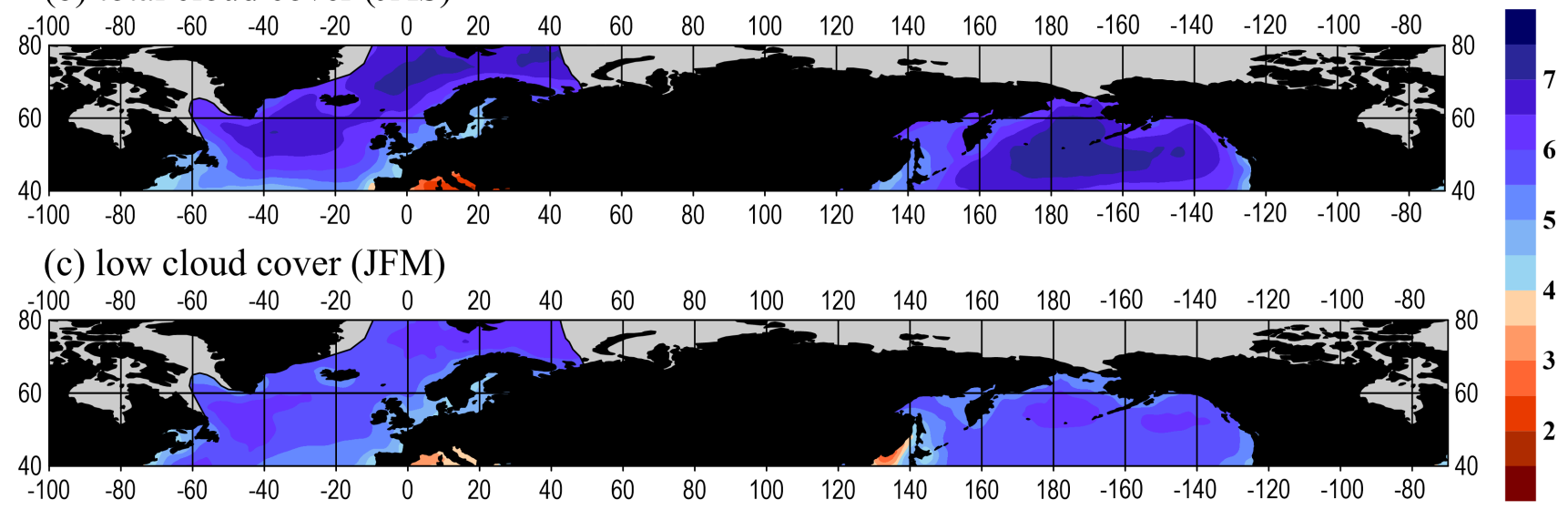

(c) low cloud cover (JFM)

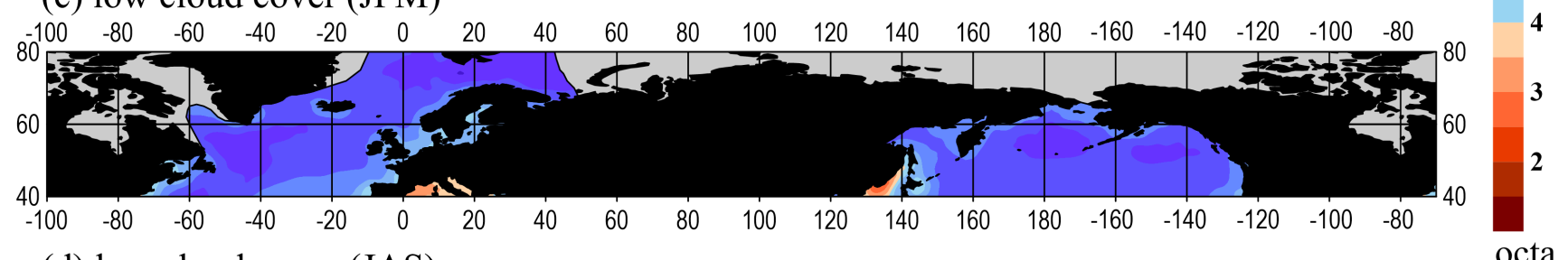

(d) low cloud cover (JAS)

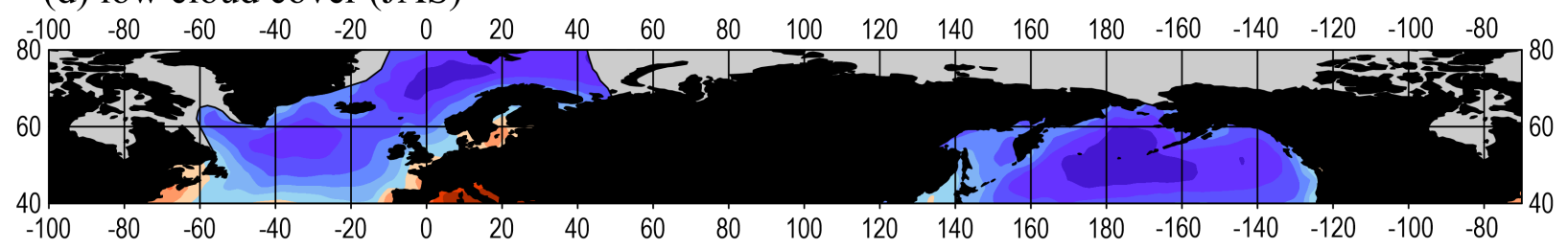

Figure 1. Climatology of the total $(\mathrm{a}, \mathrm{b})$ and low $(\mathrm{c}, \mathrm{d})$ cloud cover for JFM (a, c) and JAS (b, d) for the period 1950-2017.

cific north to $40^{\circ} \mathrm{N}$ for the period $1950-2017$, thus focusing on the regions closely related to the high latitude climate variability and impacting circumpolar latitudes. Also, the North Atlantic is a key region for the formation of low-frequency climatic variability; however, many features of this region, including cloudiness, are not analyzed sufficiently [Bekryaev, 2019].

\section{Climatology of High Latitude Cloud Cover}

We start with the climatology of fractional cloud cover for the period from 1950 to 2017. Climatological grids of fractional cloud cover based on VOS data were computed with $2^{\circ}$ spatial resolution. For fully unsampled boxes the gaps were filled by the Akima objective interpolation method. Figure 1 shows climatologies of the mean total $(\mathrm{a}, \mathrm{b})$ and low (c, d) cloud cover for JFM (a, c) and JAS, (b, d).

Figure 1 shows that the subpolar North Atlantic and the North Pacific are characterized by a considerable amount of cloud cover, which in most cases exceeds 6 octas for total cloud cover and 5 octas for the low cloud cover. In JFM for both, the North Atlantic and the North Pacific, total cloud cover is characterized by seasonal means of 6-7 octa. In summer, total cloud cover in the subpolar North Atlantic decreases in mid latitudes and increases over high latitudes (region of the Norwegian and Barents seas). In most regions of the North Pacific in JAS the total cloud cover is greater than in JFM by $0.5-1$ octa. The cloud pattern in the Sea of Japan shows the maximum cloud cover in the summer with the values for JAS not exceeding 5 octas and being less then 4 octas in JFM.

Seasonal march of the low cloud cover follows the seasonal variation of total cloud cover. In the mid- 
latitude North Atlantic the maximum cloud cover (5.5-6.5 octas) is observed in winter. In summer, the amount of low clouds here decreases to $4-5.5$ octas. In high latitudes (the Norwegian Sea and the eastern Greenland Sea), maximum low cloud cover values (6-7 octas) are observed, on the contrary, in summer. In winter, the amount of low cloud cover in this region is about 6 octas. Over the most North Pacific, there are more low level clouds in the summer than in the winter. In JAS the local maximum of low cloud cover of 7 octas is observed in the central North Pacific. In winter, over most of the North Pacific, the mean low cloud cover is ranging from 5.5 to 6.5 octas. In the Sea of Japan, there is a regional minimum of low cloud cover over the area. In JFM, the mean low cloud cover in the Sea of Japan does not exceed 2.5-3.5 octas with the summer values increasing to $4-4.5$ octas.

\section{Analysis of Probability Mass Functions}

The mean cloud cover provides incomplete information about the cloud regime. For a better understanding of the structure of the cloud cover, we analyzed the distribution of fractional cloud cover by octas [Aleksandrova et al., 2018] for the selected $10^{\circ}$ squares. Figure 2 shows that in different regions of the North Atlantic and the North Pacific the histograms of cloud cover are characterized by the increase of probability from small cloud amounts to overcast conditions ( 8 octas). In the North Atlantic (Figure 2b-Figure 2 ), changes in the shape of distribution from winter to summer are not significant. Only in the western part of the North Atlantic south of Newfoundland (Figure 2a) in summer (JAS) the frequency of overcast conditions decreases noticeably, which is consistent with the decrease in the mean total cloud cover from winter to summer in this region (Figure 1).

Over the North Pacific, the distribution of fractional total cloud cover also has a shape similar to that in the North Atlantic with the occurrences peaked at 8 octa (Figure $2 \mathrm{~s}$-Figure $2 \mathrm{k})$. However, in contrast to the North Atlantic in the western and central North Pacific in JAS the frequency of complete overcast ( 8 octas) is significantly higher than in JFM. In the eastern Pacific, near the North American coast the seasonal march in the distribution shape is less pronounced with the exception of the northwestern United States in the summer when seasonal changes in the occurrence of clear skies are noticeable. The shape of cloud cover distribution is however completely different in the Sea of Japan. Here it takes a U-shape form (Figure 2 ), with a higher occurrence of clear sky conditions in winter and of overcast conditions in summer.

Distribution of the fractional low cloud cover is more variable from region to region. In the central North Atlantic low cloud cover primarily ranges from 5 to 7 octa (Figure $3 \mathrm{~b}$-Figure 3 c) and seasonal variations are not pronounced. In the western North Atlantic (Figure $3 \mathrm{a})$, south of Newfoundland the frequency of low cloud cover peaks at 5-7 octas in JFM. In summer the frequency of the clear sky conditions increases. In the eastern North Atlantic near the coast of Norway low cloud cover occurrence has a maximum in the range from 5 to 8 octas $($ Figure 3 $\mathrm{d})$. At the same time small low cover amounts (0-2 octas) are more frequently observed than in the central North Atlantic.

Over most of the North Pacific, histograms of the low cloud cover remain those observed in the central Atlantic, with the distribution peaked at 5-7 octa. In the central North Pacific (Figure 3 Figure 3i), the seasonal variations in the shape of distribution are more pronounced than in the North Atlantic. Also, small low cloud cover (0-2 octas) is more frequently observed in JFM than in JAS. In the eastern North Pacific, near the coast of North America, the maximum frequency of low cloud cover ranges from 4 to 7 octas (Figure 3jFigure 3k), however, this region is also characterized by a second peak at 0-2 octas, that is especially pronounced in the JAS (Figure $3 \mathrm{k}$ ).

As for the total cloud cover, the Sea of Japan is characterized by very different from the other regions shape of distribution of the low cloud cover with the high occurrence of small amounts of low cloud cover which is somewhat higher in JFM compared to JAS. Also, in this region one can observed a second peak at 5-6 octas which is more pronounced in summer.

\section{Interannual Variability}

To analyze the interannual variability of cloud cover in the North Atlantic and the North Pacific, we computed linear trends and their statistical significance. Figure 4 shows the linear trends in total 

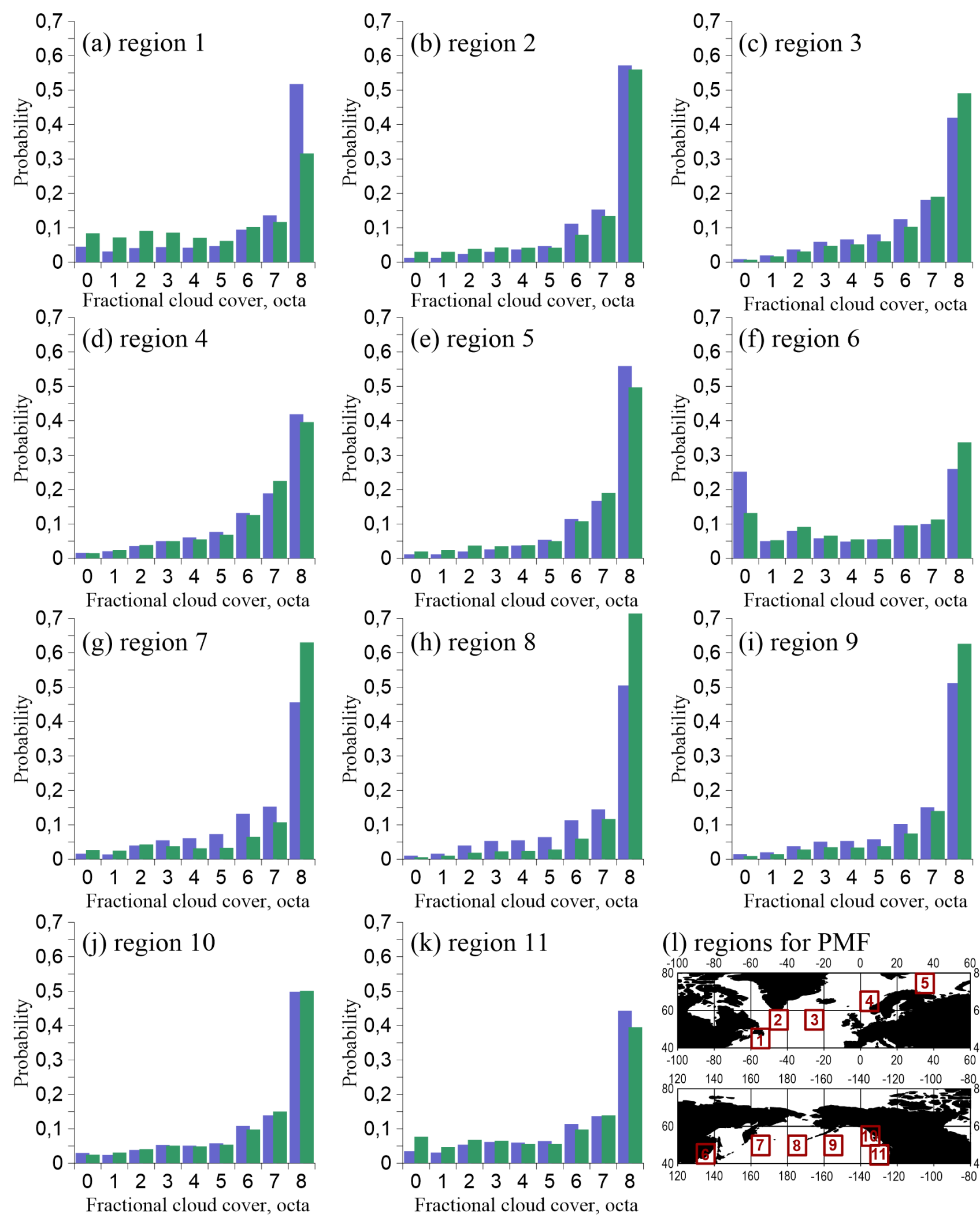

(1) regions for PMF

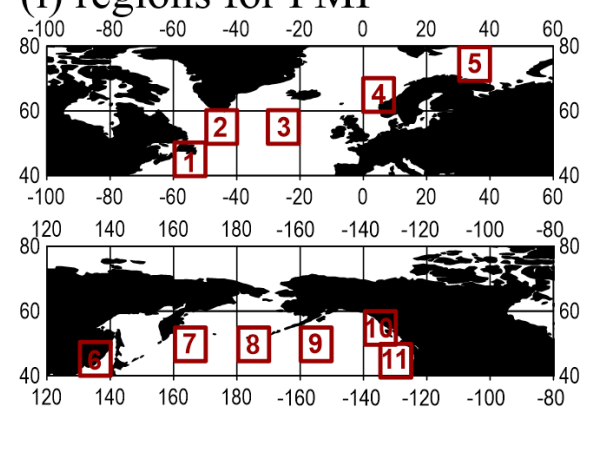

JFM

JAS

Figure 2. Empirical histograms of the fractional total cloud cover (octas) for selected regions (shown on the map (l)). 

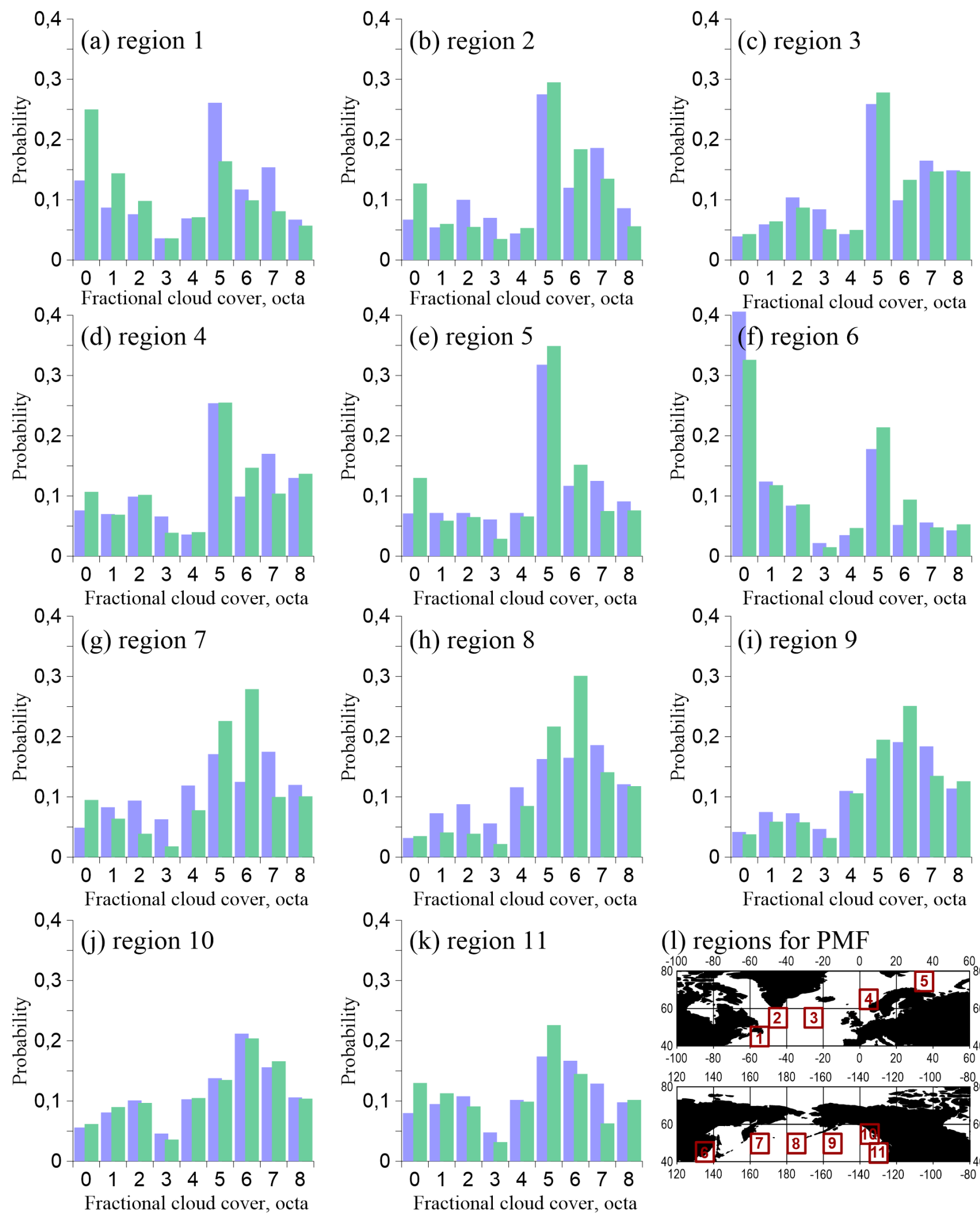

(1) regions for PMF

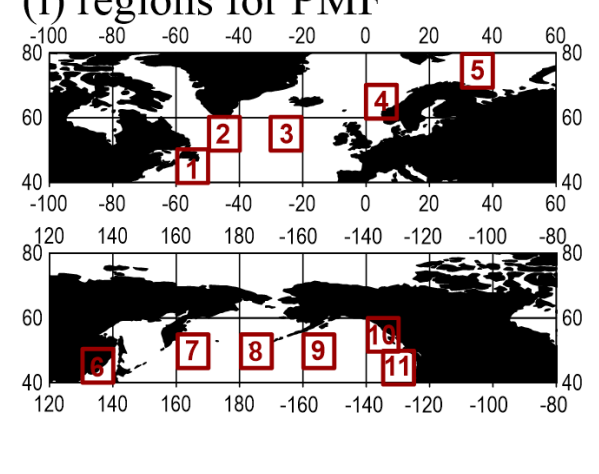

JFM

JAS

Figure 3. Empirical histograms of the fractional low cloud cover (octas) for selected regions (shown on the map (l)). 
(a) total cloud cover (JFM)

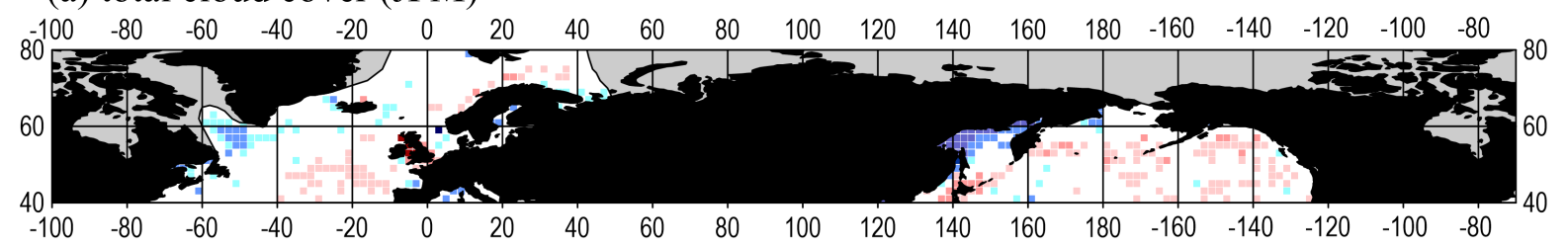

(b) total cloud cover (JAS)

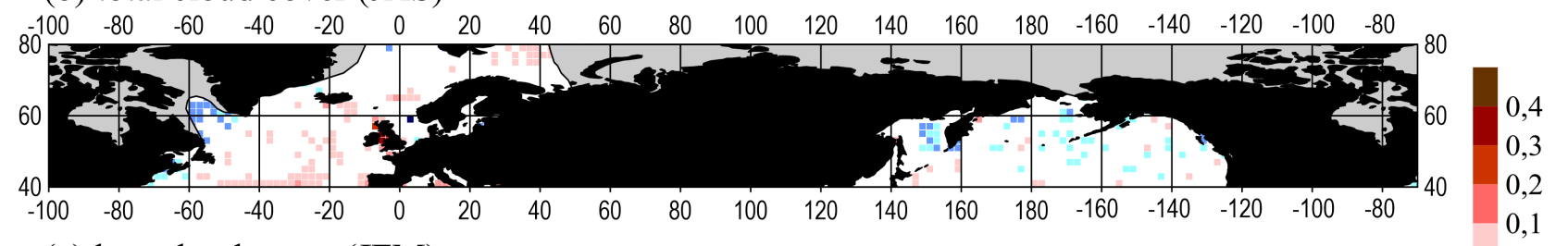

(c) low cloud cover (JFM)
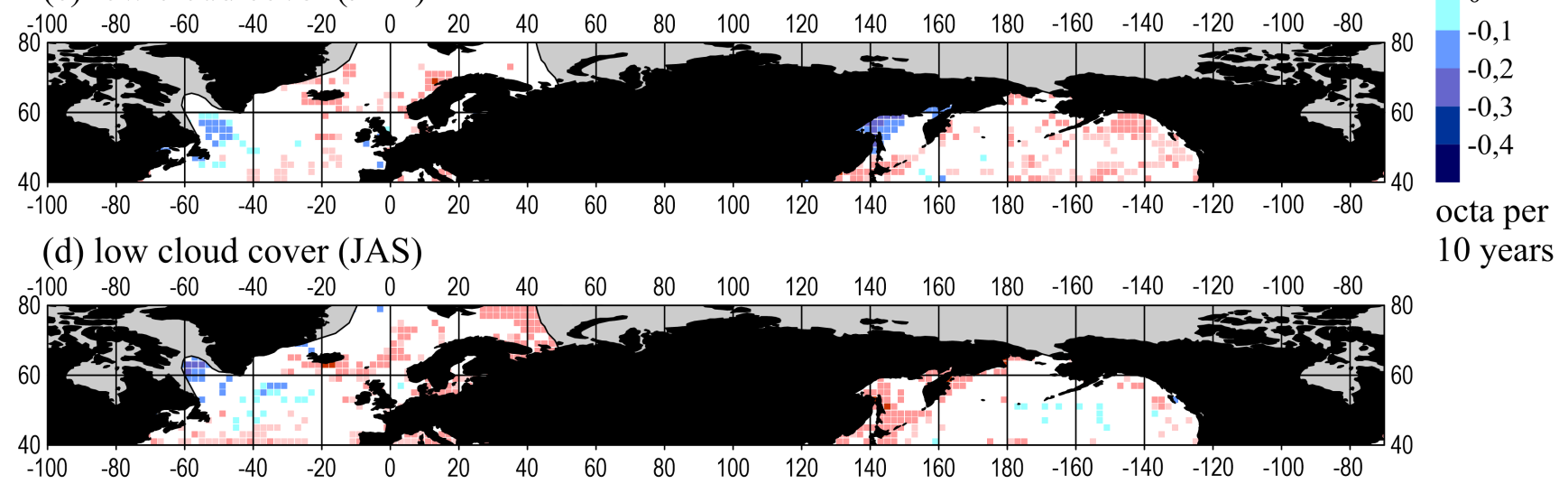

Figure 4. Linear trends in the total (a, b) and low (c, d) cloud cover for $\operatorname{JFM}(\mathrm{a}, \mathrm{c})$ and JAS (b, d) for the period 1950-2017.

and low cloud cover, which are significant at a $90 \%$ significance level according to a Student's t-test. In the North Atlantic in JFM linear trends in the total cloud cover (Figure 4a) are positive in the eastern part of the region and negative in the Labrador Sea and near Iceland. During JAS (Figure 4b) positive linear trends in the total cloud cover are observed over most of the mid- and subpolar latitudes of the North Atlantic with the negative trends being observed over the Labrador Sea. Thus, over most of the North Atlantic in recent years, there has been an increase of total cloud cover by $\sim 0.1$ octas per decade with locally high trends in the Norwegian Sea ( $\sim 0.2$ octas per decade). The western North Atlantic, the Labrador Sea region and the area near Newfoundland are characterized by a downward trends in total cloud cover (of about $-(0.1 \ldots-0.2)$ octas per decade).

In the North Pacific, linear trends in the total cloud cover are characterized by pronounced seasonality. During JFM (Figure 4 4 ) over most of the
North Pacific linear trends in the total cloud cover are positive (0.1-0.2 octas per decade) and during JAS (Figure 4p) linear trends here are primarily negative with the same magnitude. Quite a different trend pattern is observed in the Sea of Okhotsk. Here, both winter and summer trends in the total cloud cover are negative, reaching in JFM -0.3 octas per decade in the western part of the Sea of Okhotsk and being marginally significant in JAS.

Linear trends in low cloud cover in JFM (Figure 4c) are positive in the eastern North Atlantic, over the Norwegian Sea and the Greenland Sea (0.1-0.2 octas per decade). Negative winter trends in low cloud cover are observed over the Labrador Sea and south of Newfoundland amounting to -0.2 octas per decade. In JAS, the trend pattern of low cloud cover in the North Atlantic (Figure $4 \mathrm{~d}$ ) is characterized by positive trends (0.1-0.2 octas per decade) between $40^{\circ} \mathrm{N}$ and $45-48^{\circ} \mathrm{N}$ as well as in the region around Iceland and in the Norwegian Sea, where trends amount to $0.15-0.25$ octas per 
decade. Negative trends in low cloud cover in JAS are noticed between $45^{\circ} \mathrm{N}$ and $60^{\circ} \mathrm{N}(0.1-0.2$ octas per decade) and over the Labrador Sea (0.2-0.3 octas per 10 years).

In the North Pacific in winter (Figure 4k) the linear trends in both total and low cloud cover are positive with the most pronounced trend pattern being observed in the central and eastern parts of the North Pacific, where trend magnitudes amount to $0.1-0.25$ octas per decade. In most regions of the western North Pacific winter linear trends in the low cloud cover in JFM are not statistically significant. Also, positive linear trends are noted in the Sea of Japan (0.1-0.2 octas per decade). In JAS, the interannual variability of low cloud cover in the North Pacific is less pronounced than in JFM (Figure $4 \mathrm{~d}$ ). In the central part of the North Pacific, locally negative trends (not exceeding -0.1 octas per decade) should be considered with caution due to poor sampling in this region. Positive trends are also observed in JAS in the eastern North Pacific near the coast of North America, where they amount to $0.1-0.2$ octas per decade.

\section{Summary and Discussion}

We analyzed climatology and interannual variability of the cloud cover in the subpolar North Atlantic and the North Pacific using visual cloud cover observations from ICOADS. It is shown that the seasonal variations of cloud cover have different patterns in the North Atlantic and in the North Pacific. In the Atlantic, an annual maximum of mean total cloud cover observed in JAS only in high latitudes. In the $40^{\circ}-50^{\circ} \mathrm{N}$ belt, the total cloud cover in the summer is smaller than in the winter. In the North Pacific in JAS the total cloud cover is higher than in JFM. The same patterns are observed when considering the seasonal variations in low cloud cover.

Analysis of the probability distributions of fractional cloud cover shows that over most of the North Atlantic and the North Pacific the occurrence of cloud fraction increases from small to high cloud amounts being peaked at 8 octas. Over most of the North Pacific, except for the east of the region, the frequency of 8 octas of total cloud cover is higher in JAS than in JFM. This is in contrast to the North Atlantic where this seasonal dependence is not pronounced. The Sea of Japan is characterized by U-shape form of distribution which is not observed in the open ocean regions.

The histograms of the low cloud cover are most frequently peaked at 5-7 octas in both Pacific and Atlantic. Seasonal variations in the probability distributions are mostly pronounced south of Newfoundland, where the frequency of low clouds in the range $0-2$ octas is noticeably higher in JAS and the frequency of moderate cloudiness is higher in JFM. In the open ocean regions of the North Pacific, on the contrary, the frequency of moderate cloudiness is higher in the summer.

Analysis of linear trends shows an increase in the total cloud cover observed over most of the North Atlantic since the mid-20th century in both winter and summer. Locally negative trends are observed in the eastern North Atlantic regions close to Newfoundland. In the North Pacific positive trends are observed in winter while summer season is characterized by a decrease in the total cloud cover.

Analyzed dynamics of cloud cover is critically important for the further analysis of atmospheric moisture transport [Dufour et al., 2016] and its association with cyclone activity in both mid and high latitudes [Tilinina et al., 2018]. Cloud cover dynamics over western boundary currents provides insights for the further analysis of radiative fluxes which form together with turbulent fluxes the heat budget at the ocean surface [Cronin et al., 2019]. For a more detailed analysis of cloud cover in the subarctic latitudes of the North Atlantic and the North Pacific, it is useful to apply a theoretical three-parameter mixed gamma distribution for fractional cloud cover [Aleksandrova et al., 2018. Application of this distribution will help to better identify the features of cloud regimes. Also, for a more detailed understanding of the features of different regions of the Arctic, it is necessary to analyze the types of clouds. For example, Chernokulsky and Esau 2019 show that, unlike the rest of the Arctic, where correlations with atmospheric circulation indices and regional moisture transport in spring and summer are insignificant, a strong correlation in these seasons was found between moisture transport between the Barents and Kara seas and cloudiness. Such a relationship may indicate that moisture transport in spring and summer noticeably affects the higher clouds of the West and Central Eurasian Arctic. 
Acknowledgment. This work was funded by the Russian Ministry of Science and Higher Education (agreement \# 05.616.21.0112, project ID RFMEFI61619X0112).

\section{References}

Aleksandrova, M. P., S. K. Gulev, A. V. Sinitsyn (2007), Improvement of upper-ocean shortwave radiation parameterization on the base of direct measurements in the Atlantic Ocean, Meteorology and $\mathrm{Hy}$ drology, 4, 45-54, Crossref

Aleksandrova, M., S. K. Gulev, K. Belyaev (2018), Probability distribution for the visually observed fractional cloud cover over the ocean, J. Climate, 31, 3207-3232, Crossref

Bedacht, E., S. K. Gulev, A. Macke (2007), Intercomparison of global cloud cover fields over oceans from the VOS observations and NCEP/NCAR reanalysis, Int. J. Climatol., 27, 1707-1719, Crossref

Bekryaev, R. V. (2019), Interrelationships of the North Atlantic multidecadal climate variability characteristics, Russian Journal of Earth Sciences, 19, Crossref

Bekryaev, R. V., I. V. Polyakov, V. A. Alexeev (2010), Role of polar amplification in long-term surface air temperature variations and modern Arctic warming, J. Climate, 23, 3888-3906, Crossref

Chernokulsky, A. V., I. Esau (2019), Cloud cover and cloud types in the Eurasian Arctic in 1936-2012, Int. J. of Clim., 39, 5771-5790, Crossref

Chernokulsky, A. V., I. I. Mokhov (2012), Climatology of total cloudiness in the Arctic: An intercomparison of observations and reanalyses, Adv. Meteor., 2012, 542093, Crossref

Chernokulsky, A. V., et al. (2017), Climatology and interannual variability of cloudiness in the Atlantic Arctic from surface observations since the late nineteenth century, J. Climate, 30, 2103-2120, Crossref

Cronin M. F., et al. (2019), Air-sea fluxes with a focus on heat and momentum, Frontiers in Marine Science, 6, 430, Crossref

Dobson, F. W., S. D. Smith (1988), Bulk models of solar radiation at sea, Quart. J. R. Met. Soc., 114, 165-182, Crossref

Dufour, A., O. Zolina, S. K. Gulev (2016), Atmospheric moisture transport to the Arctic: assessment of reanalyses and analysis of transport components, J. Climate, 29, 5061-5081, Crossref

Foster, M. J., A. Heidinger (2013), PATMOS$\mathrm{x}$ : Results from a diurnally corrected 30-yr satellite cloud climatology, J. Climate, 26, 414-425, Crossref

Freeman, E., et al. (2017), ICOADS Release 3.0: A major update to the historical marine climate record, Int. J. Climatol., 37, 2211-2232, Crossref
Frey, R. A., et al. (2008), Cloud detection with MODIS. Part I: Improvements in the MODIS cloud mask for Collection 5, J. Atmos. Oceanic Technol., 25, 1057-1072, Crossref

Gulev, S. K., T. Jung, E. Ruprecht (2007a), Estimation of the impact of sampling errors in the VOS observations on air-sea fluxes. Part I: Uncertainties in climate means, J. Climate, 20, 279-301, Crossref

Gulev, S. K., T. Jung, E. Ruprecht (2007b), Estimation of the impact of sampling errors in the VOS observations on air-sea fluxes. Part II: Impact on trends and interannual variability, J. Climate, 20, 302-315, Crossref

Josey, S. (2003), A new formula for determining the atmospheric longwave flux at the ocean surface at mid-high latitudes, J. Geophys. Res., C4, 3108, Crossref

Karlsson, K.-G., et al. (2013), CLARA-A1: A cloud, albedo, and radiation dataset from $28 \mathrm{yr}$ of global AVHRR data, Atmos. Chem. Phys., 13, 5351-5367, Crossref

Kay, J. E., A. Gettelman (2009), Cloud influence on and response to seasonal Arctic sea ice loss, $J$. Geophys. Res., 114, D18204, Crossref

Liu, Y., J. R. Key (2016), Assessment of Arctic cloud cover anomalies in atmospheric reanalyses products using satellite data, J. Climate, 29, 60656083, Crossref

Pisareva, M. N. (2018), An overview of the recent research on the Chukchi Sea water masses and their circulation, Russian Journal of Earth Sciences, 18, Crossref

Rossow, W. B., R. A. Schiffer (1991), ISCCP cloud data products, Bull. Amer. Meteor. Soc., 72, 2-20, Crossref

Rossow, W. B., R. A. Schiffer (1999), Advances in understanding clouds from ISCCP, Bull. Amer. Meteor. Soc., 80, 2261-2287, Crossref

Serreze, M. C., R. G. Barry (2011), Processes and impacts of Arctic amplification: A research synthesis, Global Planet. Change, 77, 85-96, Crossref

Stubenrauch, et al. (2013), Assessment of global cloud datasets from satellites: Project and database initiated by the GEWEX Radiation Panel, Bull. Amer. Meteor. Soc., 94, 1031-1049, Crossref

Tilinina, N., A. Gavrikov, S. Gulev (2018), Association of the North Atlantic surface turbulent heat fluxes with midlatitude cyclones, Mon. Wea. Rev., 146, 3691-3715, Crossref

Travkin, V. S., T. V. Belonenko (2019), Seasonal variability of mesoscale eddies of the Lofoten Basin using satellite and model data, Russian Journal of Earth Sciences, 19, Crossref

Ushakov, K. V., R. A. Ibrayev (2018), Assessment of mean world ocean meridional heat transport characteristics by a high-resolution model, Russian Journal of Earth Sciences, 18, Crossref

Vlasova, G., S. Marchenko, N. Rudykh (2019), Modeling spring hydrodynamic regime of surface wa- 
ters in Kamchatka Strait, Russian Journal of Earth Sciences, 19, Crossref

Wille, et al. (2019), West Antarctic surface melt triggered by atmospheric rivers, Nature Geoscience, 12, 911-916, Crossref

WMO (1974), Manual on Codes, Vol. 1, 348 pp. World Meteorological Organization Publ., Geneva.

Woodruff, S. D., et al. (2011), ICOADS Re- lease 2.5: Extensions and enhancements to the surface marine meteorological archive, Int. J. Climate, 31, 951-967, Crossref

Corresponding author:

M. Aleksandrova, Shirshov Institute of Oceanology RAS, 36 Nakhimovsky Prospect, 117997 Moscow. 